African Journal of Microbiology Research Vol. 6(39), pp. 6773-6780, 11 October, 2012

Available online at http://www.academicjournals.org/ajmr

DOI: 10.5897/AJMR12.322

ISSN 1996-0808 @2012 Academic Journals

Full Length Research Paper

\title{
Occurrence and antibiotic resistance of enterococci in ready-to-eat food of animal origin
}

\author{
Wioleta Chajęcka-Wierzchowska*, Anna Zadernowska, Beata Nalepa and Lucja Laniewska- \\ Trokenheim
}

Department of Industrial and Food Microbiology, Faculty of Food Sciences, University of Warmia and Mazury in Olsztyn, PI. Cieszyński 1, 10-900 Olsztyn, Poland.

Accepted 24 September, 2012

\begin{abstract}
The aim of this work was to determine which Enterococcus species could be isolated from food of animal origin and the significance of these enterococcal isolates according to their antibiotic resistance profiles. Ninety-two Enterococcus strains were isolated from retail food of animal origin in Olsztyn, Poland. They were classified as Enterococcus faecalis (44 strains), Enterococcus faecium (32 strains) or Enterococcus spp. (16 strains) by phenotypic method and confirmed by polymerase chain reaction (PCR). Susceptibility of these enterococcal strains to 15 selected antibiotics (ampicillin, penicillin G, gentamicin, streptomycin, vancomycin, teicoplanin, norfloxacin, levofloxacin, ciprofloxacin, tetracycline, tigecycline, rifampicin, nitrofurantoin, linezolid, fosfomycin, chloramphenicol and quinupristin/dalfopristin) was determined using the disk diffusion method according to the recommendations of Clinical and Laboratory Standards Institute (CLSI 2010, formerly NCCLS). All the investigated strains were sensitive to levofloxacin, ciprofloxacin and vancomycin. Antimicrobial susceptibility tests showed resistance phenotypes to a range of antibiotics widely administrated in humans such as tetracycline, nitrofurantoin and quinupristin/dalfopristin.
\end{abstract}

Key words: Enterococcus spp., antibiotic resistance, food, animal origin, food safety.

\section{INTRODUCTION}

The presence of antimicrobial resistant bacteria in foodstuffs of animal origin is becoming a matter of concern as these bacteria can be transmitted to humans through food supply. Therefore, protection of food supplies includes microbiological quality and safety of commodities available for public consumption. While such concerns most frequently address pathogenic microorganisms, that present immediate risks to human health, there is growing interest in commensal components of the microbiota associated with food (Hayes et al., 2003; Martin et al., 2005; Perez-Pulido et al., 2006; Ruiz-Moyano et al., 2009).

*Corresponding author. E-mail: wioleta.chajecka@uwm.edu.pl. Tel: +48-089-5233729. Fax: +48-089-5234516.
Enterococcus ssp. constitutes part of the natural gut microflora in mammals. For many years, they have been considered harmless to man. However, Enterococcus spp. bacteria are important nosocomial pathogens with a remarkable capacity of expressing resistance to several antimicrobial agents. In the last decade, enterococci have become the second most frequently reported cause of surgical wound infections or nosocomial urinary tract infections and the third most frequently reported cause of bacteremia (Shaked et al., 2006). Moreover, treatment of enterococcal infections has become more difficult due to the increasing prevalence of antibiotic resistant enterococci (Ben-Omar et al., 2004).

The increasing incidence of antibiotic resistant Enterococcus spp. is due to the increase use of antibiotics both in the human health care system and in agriculture as animal growth promoters (Aarestrup, 2000; 
Mannu et al., 2003). The emergence of resistance to antimicrobial agents during therapy threatens the successful treatment of infections and risks the further spread of resistant organisms to other patients and to the community. In fact, there is a correlation between antibiotic use and subsequent increase in resistance (Butaye et al., 2000).

Enterococci are widespread in a variety of food products (Barbosa et al., 2009; Belicova et al., 2007; Komprda et al., 2010; Giard et al., 2001). Researchers have suggested that enterococci can transfer antibiotic resistance genes through food. It has been shown that the same antibiotic resistance genes were found in bacteria isolated from unpasteurized cheese and in bacteria isolated from human patients (Mannu et al., 2003; Ogier et al., 2008). Moreover, most of the human clinical Enterococcus spp. isolates are species that normally colonize humans (Shaked et al., 2006). These observations support the hypothesis that Enterococcus spp. found on food either directly colonize humans or exchange antibiotic resistance genes with species that colonize humans. However, there is still no demonstrated correlation between ingestion of food products containing enterococci and infections.

Studies of microorganisms present in many foods have indicated that enterococci play a dual role in some kind of food. On one hand, enterococci may be virulent to humans and express antibiotic-resistance genes. On the other hand, enterococci play an important role in the ripening of cheeses, contributing to their typical taste and flavor through proteolysis, lipolysis, and citrate metabolism (Manolopoulou et al., 2003). Enterococci are also present in other fermented foods, such as sausages (Franz et al., 2003; Giraffa, 2002) and olives (Ben-Omar et al. 2004). The contribution of enterococci to the organoleptic properties of fermented food products and their ability to produce bacteriocins active against spoilage or pathogenic bacteria, in particular Listeria, are important characteristics for their applications in food technology (Foulquié-Moreno et al., 2006; Franz et al., 2003; Sarantinopoulous et al., 2002; Valenzuela et al., 2009). However, the selection of enterococcal species for use in food processing is a difficult task, due to their potential risk to human health.

Enterococcus can survive in different environmental conditions, such as temperature ranging from 10 to $45^{\circ} \mathrm{C}$, $\mathrm{pH}$ ranging from 2.7 to 10 , or $\mathrm{NaCl}$ concentration up $6.5 \%$. They can also survive heating at a temperature of $63.5^{\circ} \mathrm{C}$ for $30 \mathrm{~min}$. The thermal resistance of enterococci explains their presence in cheeses produced from pasteurized milk. Enterococci may colonize raw foods (e.g. milk and meat) and multiply in these materials during fermentation because of their ability to survive to adverse environmental conditions such extreme $\mathrm{pH}$, temperatures and salinity (Gardin et al. 2001). The presence of Enterococcus spp. in the gastrointestinal tract of animals may lead to contamination of meat at the time of slaughtering. Besides raw meats, they are also associated with processed meats. Heating of processed meats during production may confer a selective advantage to enterococci because these bacteria are among the most thermotolerant of the non-sporulating bacteria. After surviving the heat-processing step, enterococci have been implicated in spoilage of cured meat products, such as canned hams and chub-packed luncheon meats (Magnus et al., 1986, 1988). This is especially true where recontamination with competing bacteria is prevented, when products are heated after packaging in cans or in impermeable plastic films. The heat resistance of Enterococcus spp. in these products is influenced by components such as salt, nitrite, and meat tissue (Franz et al., 1999). In fermented sausages, viable enterococci (especially E. faecium) can be found in relatively high numbers. Contaminated poultry, pork and beef can contain $10^{2}$ to $10^{4} \mathrm{cfu} \mathrm{g}^{-1}$ of viable enterococci (Teuber et al., 1996). During fermentation, the contaminating enterococci may survive and multiply. These bacteria withstand normal conditions of food production and become an important part of ready-to-eat products (Ben-Omar et al., 2004; Bhardwaj et al., 2008; Majhenic et al., 2005). In German and Italian fermented sausages, Marchesino et al. (1992) reported concentrations of Enterococcus spp. from $10^{3}$ to $10^{5} \mathrm{cfu}$ $\mathrm{g}^{-1}$ at the end of the ripening process.

The aim of the present work was to characterize Enterococcus spp. recovered from selected ready-to-eat food of animal origin, focusing on prevalence, phenotypic characteristics and resistance to antibiotics commonly used in human therapies. Our results contribute to evaluation of the microbiological risks of foods intended for human consumption, especially those from animal sources.

\section{MATERIALS AND METHODS}

\section{Samples collection}

Samples were obtained in a retail market in Olsztyn, Poland. A total of 122 samples were collected: 75 dairy products (cheeses) and 37 ready-to-eat meat products (sausages, hams, etc.). After transfer to the laboratory, food samples $(10 \mathrm{~g})$ were homogenized in $90 \mathrm{ml}$ buffered peptone water (Merck, Germany) and incubated at $37^{\circ} \mathrm{C}$ for $16 \mathrm{~h}$. Slanetz-Bartley agar was used for initial isolation of enterococci. Phenotypic criteria were used for strain isolation and colony picking of presumed enterococcal strains.

\section{Bacteria isolates}

Presumptive identification of isolates was carried out with the following tests: observation of colony characteristics and cell morphology, Gram staining, catalase and oxidase production, growth at 10 and $45^{\circ} \mathrm{C}$, growth in the presence of $6.5 \% \mathrm{NaCl}$, growth at pH 9.6 and finally growth and esculin hydrolysis on bileesculin agar (Merck, Germany). The genus Enterococcus was confirmed using the catalase and pyrrolidonyl arylamidase tests (Oxoid, United Kingdom). The species was determined by 
examining haemolysis behavior, pigment production, motility and utilization of carbon sources (ribose, arabinose, raffinose, mannitol, melibiose, lactose, sucrose, arginine, sorbitol, trehalose). Isolates were identified by phenotypic methods (Alves et al., 2004) as Enterococcus faecalis, Enterococcus faecium and Enterococcus spp. PCR assay was used to confirm species identification. Analysis was performed using specific primers: E. faecalis Forward 5'-ATCAAGTACAGTTAGTCTTTATTAG-3', reverse 5' ACGATTCAAAGCTAACTGAATCAGT- $3^{\prime}$ and E. faecium Forward 5'- TTGAGGCAGACCAGATTGACGG- 3', reverse 5'TATGACAGCGACTCCGATTCC- 3. $1 \mu \mathrm{l}$ of DNA (50 ng) was added to a mixture containing $2.5 \mu \mathrm{l}$ of $10 \times$ PCR buffer, $0.5 \mu \mathrm{l}$ each of 10 $\mathrm{mM}$ deoxynucleoside triphosphate, $2.0 \mu \mathrm{l} 25 \mathrm{mM} \mathrm{MgCl}_{2}, 0.25 \mu \mathrm{l} 5 \mathrm{U}$ of Taq polymerase, and $0.5 \mu \mathrm{l}$ of each $10 \mathrm{pmol}$ primer (Fermentas, Germany). The thermal modes and cycles of the PCR assay were adjusted according to Kariyama et al. (2000). The isolates producing an amplicon band of the appropriate size on agarose gel $(1.5 \%)$ electrophoresis were considered positive for the species identification.

\section{Antibiotics resistance tests}

Antimicrobial susceptibility was determined using the disk diffusion method. Fifteen antibiotics commonly used in the treatment of clinical infection or in agricultural procedures were tested. Their names and respective disk content were as follows: ampicillin $10 \mu \mathrm{g}$ (AMP), penicillin G $10 \mathrm{IU}(\mathrm{P})$, gentamicin $120 \mu \mathrm{g}(\mathrm{CN})$, streptomycin $300 \mu \mathrm{g}(\mathrm{S})$, vancomycin $30 \mu \mathrm{g}$ (VA), teicoplanin $30 \mu \mathrm{g}$ (TEC), norfloxacin $10 \mu \mathrm{g}$ (NOR), levofloxacin $5 \mu \mathrm{g}(\mathrm{LEV})$, ciprofloxacin $5 \mu \mathrm{g}$ (CIP), tetracycline $30 \mu \mathrm{g}$ (TE), tigecycline $15 \mu \mathrm{g}$ (TGC), rifampicin 5 $\mu \mathrm{g}(\mathrm{RD})$, nitrofurantoin $300 \mu \mathrm{g}(\mathrm{F})$, linezolid $30 \mu \mathrm{g}$ (LZD), fosfomycin $200 \mu \mathrm{g}$ (FOT), chloramphenicol $30 \mu \mathrm{g} \quad(\mathrm{CL})$ and quinupristin/dalfopristin (for E. faecium) $15 \mu \mathrm{g}$ (QD). Cartridges with commercially prepared paper disks containing the appropriate antibiotic dosage were purchased from Oxoid (United Kingdom). Disk diffusion assays were performed on Mueller-Hinton Agar (Oxoid, United Kingdom). Overnight culture of enterococcal isolates was spotted on the surface of Mueller-Hinton agar. Antibiotic discs were then placed on the plates and incubated at $37^{\circ} \mathrm{C}$. Zone diameters were recorded after $24 \mathrm{~h}$ incubation. Strains were classified as resistant and susceptible according to the criteria from CLSI (2010). E. faecalis ATCC 29212 and Staphylococcus aureus ATCC 25923 were used as quality control organisms.

\section{RESULTS}

Among the animal food samples tested, a total of 92 isolates from 122 different samples were identified as presumptive enterococci. $82.1 \%$ of the food samples analyzed were positive for enterococci, with higher prevalence in cheeses (89.9\%) compared to meat products $(69.8 \%)$. Sixty-two strains were isolated from dairy products (cheeses) and thirty isolates were obtained from ready-to-eat meat products. Of these, 44 isolates were identified as the $E$. faecium, 32 as $E$. faecalis and 16 strains as Enterococcus spp. (Table1).

All enterococcal food isolates $(n=92)$ were examined for their susceptibility to 15 antibiotics. The data obtained from the disc diffusion testing are summarized in Table 2. All of the strains were sensitive to levofloxacin, ciprofloxacin and vancomycin. The overall percentages of antimicrobial resistant isolates were: $28.3 \%$ to tetracycline, $21.7 \%$ to fosfomycin, $20.7 \%$ to tigecycline, $19.6 \%$ to teicoplanin, $8.7 \%$ to streptomycin, $7.6 \%$ to gentamycin and norfloxacin, $6.5 \%$ to rifampicin, $5.4 \%$ to quinupristin/dalfopristin, $4.3 \%$ to nitrofurantoin, $3.3 \%$ to chloramphenicol and $1.1 \%$ to ampicillin, penicillin and linezolid. Resistance to tetracycline was more frequently observed among $E$. faecalis (43.2\%) than E. faecium (7.0\%).

There were minimal differences in antimicrobial resistance profiles between cheese and meat Enterococcus isolates (Figures 1 and 2). The greatest differences in antibiotic resistance incidence between cheese and meat isolates, respectively, the incidence of antibiotic resistance between cheeses and meat Enterococcus isolates were found for tetracycline (14.7 vs. $20.0 \%$ ), tigecycline (9.4 vs. $14.7 \%$ ), fosfomycin (10.7 vs. $16.0 \%$ ) and rifampicin (1.3 vs. $5.3 \%$ ). Only one $E$. faecalis strain isolated from cheese was resistant to both ampicillin (AMPR) and penicillin pattern.

The occurrence of high-level resistance to aminoglycosides (HLR-A) in the enterococcal strains is listed according to their food source in Table 3. HLR-A was detected in $18.5 \%$ of the isolates $(13.0 \%$ from cheeses and $5.4 \%$ from meat products). These figures include high-level resistance to the two aminoglycoside antibiotics that were tested, gentamycin and streptomycin. High-level resistance to gentamycin (HLRGE) was detected in $7.6 \%$ of the isolates. The frequency of HLR-GE was higher among isolates from cheeses than among those recovered from meat products. High level resistance to streptomycin (HLR-S) was also more frequently detected from cheese isolates $(5.4 \%)$ than from meat isolates $(3.3 \%)$. Isolates resistant to both gentamycin and streptomycin were found only among the E. faecalis strains isolated from cheese.

Resistance to multiple antibiotics was observed. Of the 92 isolates tested, 27 isolates (29.34\%) were resistant to two or more antibiotics. The most frequent multipleresistance phenotypes observed were combined tetracycline and fosfomycin resistance - 10 isolates $(10.87 \%)$, or combined tetracycline, fosfomycin and tigecycline resistance -7 isolates $(7.61 \%)$. When the distribution of the antibiotic resistance according to the species was consider, it was found that $E$. faecalis possessed a higher number of resistances than $E$. faecium (Table 2).

\section{DISCUSSION}

Most of the previous studies on resistance have concentrated on enterococci isolated from clinical samples and unprocessed food samples. The present study investigated the prevalence of resistant strains isolated from retailed ready-to-eat food. The most prevalent species in our study identified in food of animal origin was $E$. faecalis (47.8\% of all isolates). Similar observations were recently reported by other European 
Table 1. Distribution of enterococci isolated from food of animal origin in Olsztyn, Poland.

\begin{tabular}{llrcrcc}
\hline & \multicolumn{5}{c}{ Number (\%) of isolates } \\
\hline Species & \multicolumn{2}{c}{$\begin{array}{c}\text { Cheese } \\
(\mathbf{n}=75)\end{array}$} & \multicolumn{2}{c}{$\begin{array}{c}\text { Meat products } \\
(\mathbf{n}=37)\end{array}$} & Total products \\
\hline E.faecalis & 32 & $(51,6)$ & 12 & $(40,0)$ & 44 & $(47,8)$ \\
E.faecium & 19 & $(31,0)$ & 13 & $(43,3)$ & 32 & $(34,8)$ \\
Enterococcus spp. & 11 & $(17,8)$ & 5 & $(16,7)$ & 16 & $(17,4)$ \\
\hline Total & 62 & $(100)$ & 30 & $(100)$ & 92 & $(100)$ \\
\hline
\end{tabular}

Abbrevations: $\mathbf{n}$-number of isolates.

Table 2. Antibiotic resistance of 92 enterococci isolated from ready-to-eat food of animal origin in Poland.

\begin{tabular}{|c|c|c|c|c|c|c|c|c|}
\hline \multicolumn{3}{|c|}{ Antimicrobial agent } & \multirow{2}{*}{\multicolumn{2}{|c|}{ E. faecalis $(n=44)$}} & \multirow{2}{*}{\multicolumn{2}{|c|}{$\begin{array}{c}\text { E. faecium } \\
(\mathrm{n}=32)\end{array}$}} & \multirow{2}{*}{\multicolumn{2}{|c|}{$\begin{array}{c}\text { Enterococcus spp. } \\
(\mathrm{n}=16)\end{array}$}} \\
\hline \multirow{2}{*}{ Group } & \multirow{2}{*}{\multicolumn{2}{|c|}{$\begin{array}{l}\text { Symbol and } \\
\text { concentration }\end{array}$}} & & & & & & \\
\hline & & & $\mathbf{R}(\%)$ & $\mathbf{S}(\%)$ & $\mathbf{R}(\%)$ & $\mathbf{S}(\%)$ & $\mathbf{R}(\%)$ & $\mathrm{S}(\%)$ \\
\hline \multirow{2}{*}{$\beta$-lactams } & AMP & $10 \mu g$ & 2,3 & 97,7 & 0 & 100 & 0 & 100 \\
\hline & $\mathbf{P}$ & $10 \mathrm{IU}$ & 2,3 & 97,7 & 0 & 100 & 0 & 0 \\
\hline \multirow{2}{*}{ aminoglycosides } & $\mathrm{CN}$ & $120 \mu g$ & 9,1 & 90,9 & 25 & 75 & 6,3 & 93,7 \\
\hline & $S$ & $300 \mu \mathrm{g}$ & 9,1 & 90,9 & 9,4 & 90,6 & 6,3 & 93,7 \\
\hline \multirow{2}{*}{ peptides } & VA & $30 \mu \mathrm{g}$ & 0 & 100 & 0 & 100 & 0 & 100 \\
\hline & TEC & $30 \mu \mathrm{g}$ & 22,7 & 77,3 & 15,6 & 84,4 & 18,8 & 81,3 \\
\hline \multirow{3}{*}{ quinolones } & NOR & $10 \mu g$ & 2,3 & 97,7 & 12,5 & 87,5 & 12,5 & 87,5 \\
\hline & LEV & $5 \mu \mathrm{g}$ & 0 & 100 & 0 & 100 & 0 & 100 \\
\hline & CIP & $5 \mu \mathrm{g}$ & 0 & 100 & 0 & 100 & 0 & 100 \\
\hline \multirow{2}{*}{ tetracyclines } & TE & $30 \mu \mathrm{g}$ & 43,2 & 61,4 & 21,9 & 78,1 & 0 & 100 \\
\hline & TGC & $15 \mu g$ & 27,3 & 72,7 & 31,3 & 68,8 & 12,5 & 87,5 \\
\hline ansamicins & RD & $5 \mu \mathrm{g}$ & 6,8 & 93,2 & 6,3 & 93,8 & 6,3 & 93,7 \\
\hline nitrofurans & $\mathbf{F}$ & $300 \mu g$ & 4,5 & 95,5 & 3,1 & 96,9 & 6,3 & 93,7 \\
\hline oxazolidinones & LZD & $30 \mu \mathrm{g}$ & 2,3 & 97,7 & 0 & 100 & 0 & 100 \\
\hline fosfomycins & FOT & $200 \mu g$ & 34,1 & 65,9 & 28,1 & 71,9 & 12,5 & 87,5 \\
\hline amfenicols & C & $30 \mu \mathrm{g}$ & 4,5 & 95,5 & 0 & 100 & 6,3 & 93,7 \\
\hline streptogramins & QD & $15 \mu \mathrm{g}$ & - & - & 34,4 & 65,6 & 31,3 & 68,7 \\
\hline
\end{tabular}

Abbrevations: R-resistant, S-sensitive, $\mathbf{n}$-number of isolates, \%-percent of isolates resistant/sensitive, AMPampicillin, P-penicillin, CN-gentamicin, S- streptomycin, VA-vancomycin, TEC-teicoplanin, NOR-norfloxacin, LEVlevofloxacin, CIP-ciprofloxacin,TE- tetracycline, TGC-tigecycline, RD-rifampicin,F- nitrofurantoin, LZD-linezolid, FOT-fosfomycin, C-chloramphenicol, QD-quinupristin/dalfopristin (for E. faecium).

researchers. Andrighetto et al. (2001) found that most strains isolated from Italian cheeses were E. faecalis. Likewise, E. faecalis was the dominant species isolated from milk or Irish Cheddar-type cheese (Gelsomino et al., 2001). Klein (2003) concluded that $E$. faecalis is found more often in food and faeces from animal origin than $E$. faecium, possibly because these foods (especially cheeses) are manipulated by hands and thereby contaminated during the manufacturing process.

Enterococcus spp. are intrinsically resistant to a large wide of antimicrobials of therapeutic use. They also have the ability to acquire and transfer genetic resistance markers, a process mediated by genes present in plasmids or transposons that facilitate their dissemination (Martin et al., 2005). Enterococci are considered intrinsically resistance to $\beta$-lactams (Kak and Chow, 2002). Our results do not agree with this generalization since only one of our isolates was resistant to ampicillin and penicillin. Similar results were obtained by other authors (McGowan-Spicer et al., 2008; Valenzuela et al., 2008).

We observed resistance to several other antibiotics, 


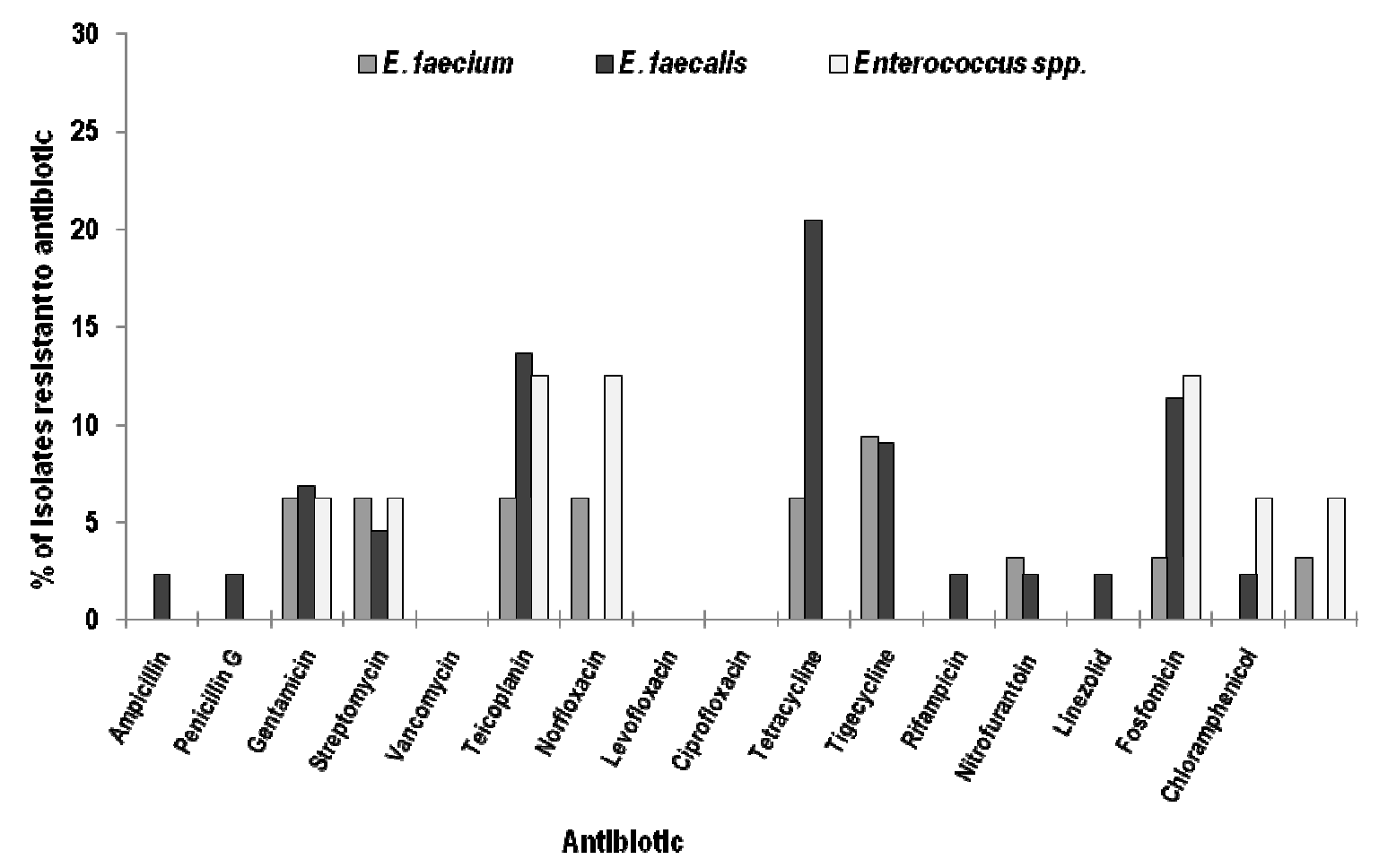

Figure 1. Distribution of antibiotic resistant E. faecium, E.faecalis and Enterococcus spp. strains isolated from cheeses.

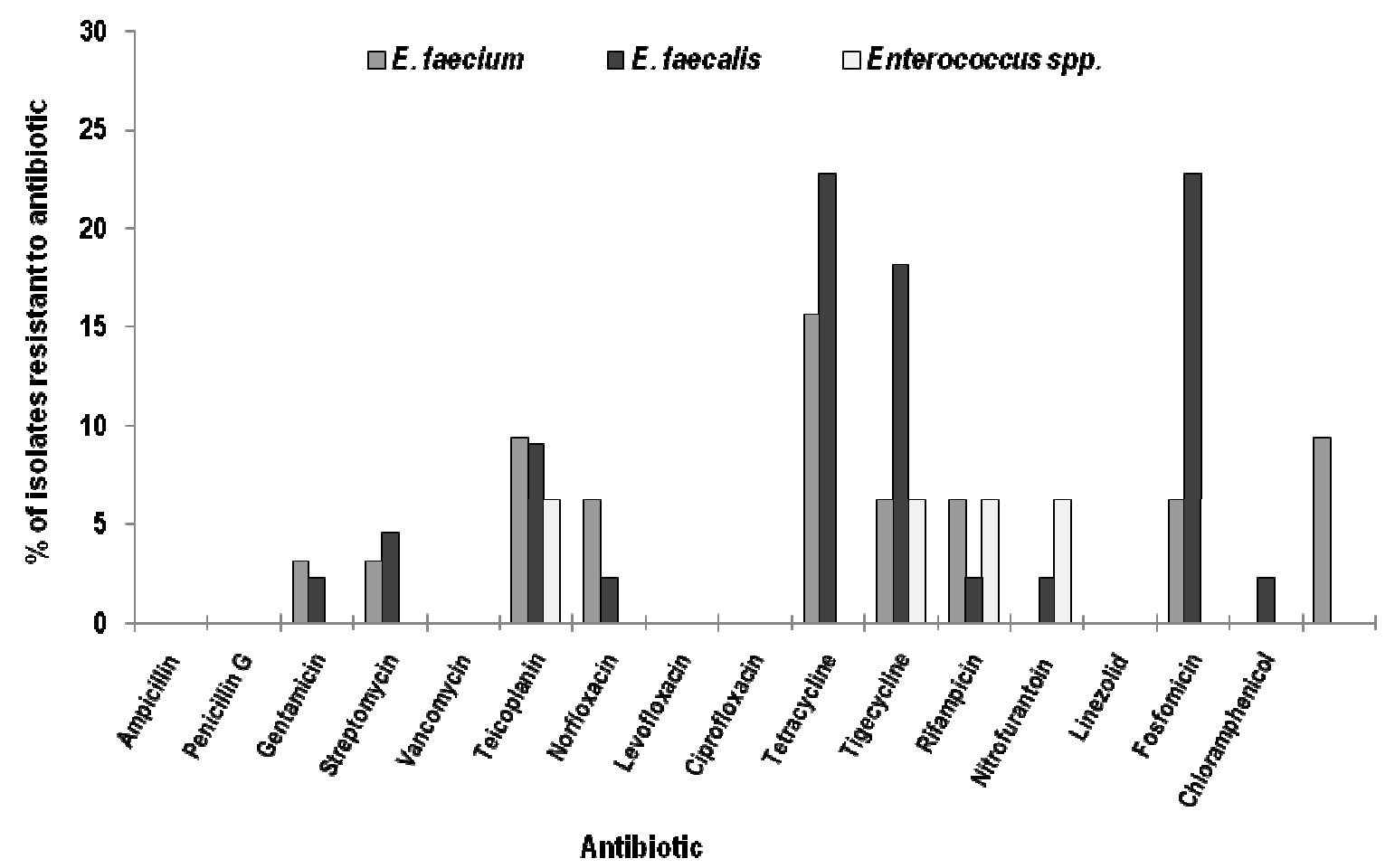

Figure 2. Distribution of antibiotic resistant E. faecium, E.faecalis and Enterococcus spp. strains isolated from ready-to-eat meat products. 
Table 3. Occurrence of high level aminoglycoside resistance (HLR-A) among enterococci strain isolated from food of animal origin.

\begin{tabular}{|c|c|c|c|c|c|c|c|c|c|}
\hline \multirow{3}{*}{$\begin{array}{l}\text { Species } \\
\text { E.faecalis }\end{array}$} & \multicolumn{9}{|c|}{ Number (\%) of resistance strain with phenotype HLR-A } \\
\hline & \multirow{2}{*}{$\begin{array}{l}\text { Source } \\
\text { cheese }\end{array}$} & \multicolumn{2}{|c|}{ HLR-GE } & \multicolumn{2}{|c|}{ HLR-ST } & \multicolumn{2}{|c|}{ HLR-GE/ST } & \multicolumn{2}{|c|}{ Total } \\
\hline & & 3 & $(6,8)$ & 2 & $(4,5)$ & 1 & $(2,3)$ & 6 & $(13,6)$ \\
\hline$(n=44)$ & meat & 1 & $(2,3)$ & 2 & $(4,5)$ & & - & 3 & $(6,8)$ \\
\hline E.faecium & cheese & 2 & $(6,3)$ & 2 & $(6,3)$ & & - & 4 & $(12,5)$ \\
\hline$(n=32)$ & meat & 1 & $(3,1)$ & 1 & $(3,1)$ & & - & 2 & $(6,3)$ \\
\hline Enterococcus spp. & cheese & & - & 1 & $(6,3)$ & 1 & $(6,3)$ & 2 & $(12,5)$ \\
\hline$(n=16)$ & meat & & - & & & & - & & - \\
\hline Total $(n=92)$ & & 7 & $(7,6)$ & 19 & $(7,1)$ & 1 & $(0,4)$ & 17 & $(18,5)$ \\
\hline
\end{tabular}

Abbrevations: HLR-A - high-level resistance to aminoglycosides (gentamycin and streptomycin); HLR-GE - high-level resistance to gentamycin; HLRST - high-level resistance to streptomycin; HLR-GE/ST - high-level resistance to both gentamycin and streptomycin.

including the aminoglycosides: streptomycin and gentamicin. Since gentamycin and streptomycin are not registered for use in animals in Poland, the prevalence of resistance was unexpected. Aminoglycosides are considered antimicrobials of choice to treat enterococcal infections (in combination with glycopeptides and/or $\beta$ lactams), so the possibility that resistance to these antibiotics could disseminate through the food chain is alarming. Our results provide a clear warning about highlevel resistance to the aminoglycosides streptomycin and gentamicin among enterococci from food of animal origin, which has not previously been observed in Europe (Hayes et al., 2004; Busani et al., 2004; Junco et al., 2005; De Jong et al., 2009).

Tetracyclines are broad-spectrum antibiotics frequently used in the treatment of humans and animals infections (Chopra and Roberts, 2001). The high prevalence of resistance to tetracycline is determined in this study (28.3\% of isolated strains) may have resulted from the frequent use of this antibiotic in veterinary medicine in Poland. Tetracycline resistance has been previously reported at high frequency among enterococcal isolates from different sources (Aarestrup, 2000; Butaye et al., 2000; Pavia et al., 2000). A high incidence of tetracycline resistance $(68 \%)$ was recently found among enterococci isolated from raw milk cheeses, where it was associated with chloramphenicol and erythromycin resistance (Templer and Baumgartner, 2007). In our study of the tetracycline resistant enterococci, $75 \%$ also showed resistance to tigecycline and $60 \%$ were also resistant to fosfomycin.

It is worrying that enterococci resistant to quinupristin/dalfopristin (Q/D) were observed, because these antibiotics are considered to be the last line of treatment against vancomycin-resistant Enterococcus spp. Streptogramin resistance in enterococci could be an example of cross-resistance. Synercid ${ }^{\circledR}$, a semisynthetic streptogramin-derived antibiotic containing dalfopristin and quinupristin (Kehoe et al., 2003). Synercid ${ }^{\circledR}(Q / D)$ was approved for the treatment of vancomycin-resistant E. faecium (Hancock, 2005). Virginiamycin, an analogue of Synercid, has been used in animal production for over two decades and it is therefore possible that $Q / D$ resistant $E$. faecium have already emerged in the animal population, which could be disseminated among humans and thus impact treatment (Hancock, 2005; Hershberger et al., 2004).

The use of chloramphenicol for treatment of human infections is low. In animal husbandry, chloramphenicol use was banned in Europe in 1994. Our results showed that almost all the isolates $(96.7 \%)$ were sensitive to chloramphenicol. Other authors (Riboldi et al., 2009) also reported low incidence of chloramphenicol resistant enterococci isolated from food.

Our results revealed that both $E$. faecium and $E$. faecalis are resistant to several antimicrobials used in human medicine such as tetracycline, nitrofurantoin and teicoplanin. Resistance to nitrofurantoin, an antibiotic used for treatment of genitourinary tract infections, was observed among cheese isolates. Enterococcus spp. strains were also found resistant to norfloxacin, a drug used to treat urinary tract infections.

The observation of susceptibility results of strains isolated from cheeses (Figure 1) was consistent with previous results from Franz et al. (2001). They studied 47 $E$. faecalis strains, isolated mostly from cheeses, that were all susceptible to vancomycin, but mostly resistant to chloramphenicol, streptomycin, tetracycline, erythromycin, ciprofloxacin, gentamicin, penicillin and ampicillin. The absence of vancomycin resistant enterococci in our study is consistent with previous observations (Hayes et al., 2003; Olawale et al., 2010). In contrast, vancomycin resistant enterococci are frequently isolated from raw meat products (Busani et al., 2004; Pavia et al., 2000) from European countries as a result of selection of resistant populations by the use of the glycopeptide avoparcin in food animal production environments (Aarestrup, 2000; Mannu et al., 2003).

The high prevalence of antibiotic resistance observed in our study suggests that bacteria in food of animal origin can be a significant reservoir of antibiotic-resistant bacteria. Similar conclusions have been suggested from 
previous studies (De Young et al., 2009; Gifaffa, 2002; Franz et al., 2003; Hammerum et al., 2004). The emergence of Enterococcus sp. expressing antimicrobial resistance and its potential spread in food suggest a situation of public health risk for the community. Effective control strategies are required to reduce contamination of foodstuffs by these microorganisms to prevent potential spread of antibiotic resistance.

\section{ACKNOWLEDGEMENT}

This research was supported by grant Ministry of Science and Higher Education, Poland N N312 236138.

\section{REFERENCES}

Aarestrup FM (2000). Occurrence, selection and spread of resistance to antimicrobial agents used for growth promotion for food animals in Denmark. APMIS Suppl. 101:1-48.

Alves PI, Martin SM, Semedo T, Figueiredo Marques JJ, Tenreiro R, Barreto Crespo MT (2004). Comparison of phenotypic and genotypic taxonomic methods for the identification of dairy enterococci. Antonie van Leeuwenhoek 85:3:237-252.

Andrighetto C, Knijff E, Lombardi A, Torriani S, Vancanneyt M, Kersters K, Swings J, Dellaglio F (2001). Phenotypic and genetic diversity of enterococci isolated from Italian cheeses. J. Dairy Res. 68:303-316.

Barbosa J, Ferreira V, and Teixeira P (2009). Antibiotic susceptibility of enterococci isolated from traditional fermented meat products. Food Microbiol. 26:527-532.

Belicova A, Krizkova L, Krajcovic J, Jurkovic D, Sojka M, Ebringer L and Dusinsky R (2007). Antimicrobial susceptibility of Enterococcus species isolated from slovak bryndza cheese. Folia Microbiol. 52:115119.

Ben-Omar N, Castro A, Lucas R, Abriouel H, Yousif NMK, Franz CMAP (2004). Functional and safety aspects of Enterococci isolated from different Spanish foods. Syst. Appl. Microbiol. 27:118-130.

Bhardwaj A, Malik RA, Chauhan P (2008). Functional and safety aspects of enterococci in dairy foods. Indian J. Microbiol. 48:317-325.

Busani L, Del Grosso M, Paladini C, Graziani C, Pantosti A, Biavasco F, Caprioli A (2004). Antimicrobial susceptibility of vancomycinsusceptible and-resistant enterococci isolated in Italy from raw meat products, farm animals, and human infections. Int. J. Food Microbiol. 97:17-22.

Butaye P, Van Damme K, Devriese L A, Van Damme L, Baele M, Slauwers, Haesebrouck E (2000). In vitro susceptibility of Enterococcus faecium isolated from food to growth-promoting and therapeutic antibiotics. Int. J. Food Microbiol. 54:181-187.

Chopra I, Roberts M (2001). Tetracycline antibiotics: mode of action, applications, molecular biology, and epidemiology of bacterial resistance. Microbiol. Mol. Biol. Rev. 65:232-260.

De Jong A, Bywater R, Butty P, Deroover E, Godinho K, Klein U, Marion H, Simjee S, Smets K, Thomas V, Vallé M, Wheadon A (2009). A pan-European survey of antimicrobial susceptibility towards humanuse antimicrobial drugs among zoonotic and commensal enteric bacteria isolated from healthy food producing animals. J. Antimicrob. Chemother. 63:733-744.

Foulquié-Moreno MR, Sarantinopoulos P, Tsakalidou E, De Vuyst L (2006). The role and application of enterococci in food and health. Int. J. Food. Microbiol. 106:1-24.

Franz CM, Holzapfel WH, Stiles ME (1999). Enterococci at the crossroads of food safety? Int. J. Food Microbiol. 47:1-24.

Franz CM, Muscholl-Silberhorn AB, Yousif NMK, Vancanneyt M, Swings J, Holzapfel WH (2001). Incidence of virulence factors and antibiotic resistance among enterococci isolated from food. Appl. Environ. Microbiol. 67:4385-4389.

Franz CM, Stiles ME, Schleifer KH, Holzapfel WH (2003). Enterococci in foods - a conundrum for food safety. Int. J. Food Microbiol. 88:105122.

Gardin F, Martuscelli M, Caruso MC, Galgano F, Crudele MA, Favati F (2001). Effects of $\mathrm{pH}$, temperature and $\mathrm{NaCl}$ concentration on the growth kinetics, proteolytic activity and biogenic amine production of Enterococcus faecalis. Int. J. Food Microbiol. 64:105-117.

Gelsomino R, Vancanneyt M, Condon S, Swings S, Cogan TM (2001). Enterococcal diversity in the environment of an Irish cheddar-type cheesemaking factory. Int. J. Food Microbiol. 71:177-188.

Giard JC, Laplace JM, Rincé A, Pichereau V, Benachour A, Leboeuf C, Flahaut S, Auffray Y, Hartke A (2001). The stress proteome of Enterococcus faecalis. Electrophoresis 22:2947-2954.

Giraffa G (2002). Enterococci from foods. FEMS Microbiol. Rev. 26:163171.

Hammerum AM, Lester CH, Neimann J, Porsbo LJ, Olsen KL, Jensen LB, Emborg HD, Wegener HC, Frimond-Moller N (2004). A vancomycin-resistance Enterococcus faecium isolated from a Danish healthy volunteer, detected 7 years after the ban of avopacin, is possibly related to pig isolates. J. Antimicrob. Chemioter. 53:547-549.

Hancock RE (2005). Mechanisms of action of newer antibiotics for Grampositive pathogens. Lancet Inf. Dis. 5:209-218.

Hayes JR, Enghish LL, Carter PJ, Proescholt T, Lee KY, Wagner DD, White DG (2003). Prevalence and antimicrobial resistance of Enterococcus species isolated from retail meats. Appl. Environ. Microbiol. pp.7153-7160.

Hayes JR, English LL, Carr LE, Wagner DD, Joseph SW (2004). Multiple antibiotic resistance of Enterococcus spp. isolated from commercial poultry production environments. Appl. Environ. Microbiol. 70:6005-6011.

Hershberger E, Donabedian S, Konstantinou K, Zervos MJ (2004). Quinupristin-dalfopristin resistance in gram-positive bacteria: mechanism of resistance and epidemiology. Clin. Inf. Dis. 38:92-98.

Junco MTT, Rodirguez OA, Barrasa JLM, Martin MG (2005). Antimicrobial susceptibility of Enterococcus strains isolated from poultry faeces. Res. Vet. Sci. 78:33-38.

Kak V, Chow JW (2002). Acquired antibiotic resistances in enterococci. In: Gilmore, M.S. (ed.) The Enterococci: Pathogenesis, Molecular Biology and Antibiotic Resistance. American Society for Microbiology, Washington, pp.355-383.

Kariyama R, Mitsuhata R, Chow JW, Clewell DB, Kumon H (2000). Simple and reliable multiplex PCR assay for surveillance isolates of vancomycin-resistant enterococci. J. Clin. Microbiol. 38:3092-3095.

Kehoe LE, Snidwongse J, Courvalin P, Rafferty JB, Murray IA (2003). Structural basis of Synercid ${ }^{\circledR}$ (Quinupristin-Dalfopristin) resistance in Gram-positive bacterial pathogens. J. Biol. Chem. 278:29963-29970.

Klein G (2003). Taxonomy, ecology and antibiotics resistance of enterococci from food and the gastrointestinal tract. Int. J. Food Microbiol. 88:123-131.

Komprda T, Sladkova P, Petirova E, Dohnal V, Burdychova R (2010). Tyrosine- and histidine-decarboxylase positive lactic acid bacteria and enterococci in dry fermented sausages. Meat Sci. 86:870-877.

Magnus CA, Ingledew WM, Mccurdy AR (1986). Thermal resistance of streptococci isolated from pasteurized ham. Can. Inst. Food Sci. Technol. J. 19:62-67.

Magnus CA, Ingledew WM, Mccurdy AR, Ingledew WM (1988). Further studies on the thermal resistance of Streptococcus faecium and Streptococcus faecalis in pasteurized ham. Can. Inst. Food Sci. Technol. J. 21:209-212.

Majhenic AC, Rogelj I, Perko B (2005). Enterococci from tolminc cheese: Population structure, antibiotic susceptibility and incidence of virulence determinants. Int. J. Food Microbiol. 102:239-244.

Mannu L, Paba A, Daga E, Comunian R, Zanetti S, Dupre I, Sechi LA (2003). Comparison of the incidence of virulence determinants and antibiotic resistance between Enterococcus faecium strains of dairy, animal and clinical origin. Int. J. Food Microbiol. 88:291-304.

Manolopoulou E, Sarantinopoulos P, Zoidou E, Aktypis A, Moschopoulou E, Kandarakis IG (2003). Evolution of microbial populations during traditional Feta cheese manufacture and ripening. Int. J. Food Microbiol. 82:153-161.

Marchesino B, Bruttin A, Romailler N, Moreton RS (1992). Microbiological events during commercial meat fermentations. J. Appl. Bacteriol. 73:203-209. 
Martin B, Garriga M, Hugas M, Aymerich T (2005). Genetic diversity and safety aspects of enterococci from slightly fermented sausages. J. Appl. Microbiol. 98:1177-1190.

Mcgowan-Spicer LL, Fedorka-Cray PJ, Frye JG, Meinersmann RJ (2008). Antimicrobial resistance and virulence of Enterococcus faecalis isolated from retail food. J. Food Prot. 71:760-769.

Ogier JC, Serror P (2008). Safety assessment of dairy microorganisms: The enterococcus genus. Int. J. Food Microbiol. 126:291-301.

Olawale AK, Akintobi AO, Famurewa O (2010). Prevalence of antibiotic resistant enterococci in fast food outlets in Osun State Nigeria. N. Y. Sci. J. 3:70-75

Pavia M, Nobile CG, Salpietro L, Angelillo IF (2000). Vancomycin resistance and antibiotic susceptibility of enterococci in raw meat. J. Food Prot. 63:912-915.

Perez-Pulido R, Abriouel H, Ben Omar N, Lucas R, Martinez-Canamero M, Galvez A (2006). Safety and potential risks of enterococci isolated from traditional fermented capers. Food Chem. Toxicol. 44:20702077.

Riboldi GP, Frazzon J, Alves D'azevedo P, Guedes Frazzon AP (2009). Antimicrobial resistance profile of Enterococcus spp isolated from food in southern Brazil. Braz J Microbiol. 40:125-128.

Ruiz-Moyano S, Martin A, Benito MJ, Aranda E, Casquete R, Cordoba MD (2009). Safety and functional aspects of preselected enterococci for probiotic use in Iberian dry-fermented sausages. J. Food Sci. 74:398-404.

Sarantinopoulous P, Kalantzopoulous G, Tsakalidou E (2002). Effect of Enterococcus faecium on microbiological, physicochemical and sensory characteristics of Greek Feta cheese. Int. J. Food Microbiol. 76:93-105.

Shaked H, Carmeli Y, Schwartz D, Siegman-Igra Y (2006). Enterococcal bacteraemia: epidemiological, microbiological, clinical and prognostic characteristics, and the impact of high level gentamicin resistance. Scand. J. Inf. Dis. 38:995-1000.

Templer SP, Baumgartner A (2007). Enterococci from Appenzeller and Schabziger raw milk cheeses: Antibiotic resistance, virulence factors and persistence of particular strains in the products. J. Food Prot. 70:450-455.
Teuber M, Perreten V, Wirsching F (1996). Antibiotikumresistente Bakterien: eine neue Dimension in der Lebensmittelmikrobiologie. Lebensmittel-Technologie 29:182-199.

Valenzuela AS, Ben-Omar N, Abriouel H, Lopez RL, Ortega E, Canamero MM, Galvez A (2008). Risk factors in enterococci isolated from foods in Morocco: determination of antimicrobial resistance and incidence of virulence traits. Food Chem. Toxicol. 46:2648-2652.

Valenzuela AS, Ben-Omar N, Abriouel H, Lopez RL, Veljovic K, Canamero MM, Topisirovic MKL, Galvez A (2009). Virulence factors, antibiotic resistance, and bacteriocins in enterococci from artisan foods of animal origin. Food Control 20:381-385.

CLSI (2010). Performance Standards for Antimicrobial Susceptibility Testing; Twentieth Informational Supplement (Document M100-S20U), Wayne, PA. 